data, which in the light of this view has already been described ${ }^{1}$, indicates that the experimental evidence is in better agreement with a uniform pair bond theory than with a single-electron bond theory of valency. A full report will be given elsewhere.

H. LESSHEIM.

Muslim University,

R. SAMUEL.

Aligarh.

Dec. 10.

${ }^{1}$ R. F. Hunter and R. Samuel, J. Chem. Soc., 1180; 1934.

\section{Reafforestation of Forest Trees in Great Britain}

Several letters and articles have recently appeared in the public Press directing attention to the necessity for the reafforestation of the hardwood trees of Great Britain.

The Forestry Commission appointed shortly after the War for the purpose of replacing the losses resulting from the excessive war demand for home grown timber, has now had about fifteen years of steady work. The Commissioners were empowered to purchase land, and plant woodlands throughout the country ; but their efforts have been confined mostly to the planting of softwoods, and with the exception of some limited areas there has been little or no planting of hardwood trees.

It is not generally realised that for quite a considerable time before the War, and during the years which have passed since, vast quantities of trees of oak, and ash, beech, walnut, etc. have been hewn down and gone into consumption. The destruction has proceeded on a scale far beyond anything which occurred during the previous hundred years, and now gradually every tree which is realisable has to come down, including every kind which possesses a monetary value, whether of mature growth or wholly immature. The tragic condition is particularly noticeable throughout Sussex, a county which was formerly one of our most beautifully wooded and richest in hardwoods.

Anyone who has travelled over long distances in India, America, and other parts of the earth, has seen areas which thoughtless men have denuded of all trees and are now barren wastes. We are bringing about the same condition in England, and Sussex is by no means the only county which has suffered. As a writer has said : "Wherever man has settled the forests disappear. Up till now the march of civilisation has everywhere proclaimed the destruction of trees over the wide surface of the globe."

In 1925 I read a paper on this subject at the meeting of the British Association at Southampton, and again each year excepting one at the subsequent meetings until that in London in 1931; but the public is still quite unaware of the true state of affairs. It is not realised that the once beautifully timbered parks and woodlands throughout the country are being completely wiped out.

Great Britain has been famous all over the world for the beauty and wealth of her woodlands, and because of the planting done by our landowners we were able before the War to boast of a fully sufficient reserve of valuable timber. The "march of civilisation" has overtaken us, and unless something is done there will be no escape from a deplorable result. The Irish Free State has handled this situation, and under the Forestry Act of 1928 made very stringent orders for the protection of its woodlands. Application has to be made to the Department of Lands, Forestry Division, Dublin, and permits must be obtained by "any person who wishes to fell any tree on his holding", and licences may contain stipulations for replacement. In England, Scotland and Wales, thousands of hardwood trees have been cut down and practically nothing planted; in southern Europe for every tree that is allowed to be felled hundreds are planted. There must surely be something seriously wrong with us if we allow this state of affairs to continue.

\section{8, Trinity Square, London, E.C.3.}

Alexander L. Howard.

\section{Interpretation of Animal Behaviour}

IN a recent article on the "Interpretation of Animal Behaviour"1 the view was advanced that a preoccupation with teleological explanations was necessarily somewhat unscientific and philosophical.

Since the future development of psychology-and probably of biology-will depend largely on whether men of science agree to recognise the validity of purposive concepts or decide to consider them as being inadmissible, the question is of great importance. Already, the nature and content of the problems investigated depend largely on what the investigators concerned think on this point.

It is generally agreed, of course, that science necessarily operates in a world of objective fact and that it must be deterministic. But it is unwise to assume that vitalistic theories or teleological interpretations are less scientific and deterministic, or more metaphysical, than are mechanical theories using efficient causation. After all, the facts alone can be considered objective and all modes of interpretation or of analysis of them are, in a sense, subjective.

Again, the doctrines of efficient and of final causation are both philosophical in so far as they are merely principles of explanation not themselves contained in the facts studied. Nor can it be maintained that preoccupation with teleology is necessarily unscientific. In fact, the principal claim of the vitalist school is that the category of final causation is a legitimate weapon of scientific analysis, capable of being applied rigidly to particular problems. It is difficult to understand why unfortunate teleologists should necessarily be relegated to the same scrapheap as the universally despised metaphysicians !

Both the believers in efficient causation and the teleologists agree on one point : the present moment is not understandable in isolation. Mechanists insist that the past is immanent in the present, teleologists insist that the future is equally immanent in the present. Clearly both are justified in their beliefs, but why should the latter alone be condemned as unscientific anthropomorphs ?

If I may paraphrase Prof. A. N. Whitehead, is it not true to say that those psychologists who are animated by the purpose of showing that neither they themselves nor the animals have purposes, form an interesting subject for psychological investigation?

Institute of Education,

J. A. LAUWERys.

Southampton Row,

London, W.C.1. Jan. 16.

${ }^{1}$ NATURE, 134, 996, Dec. 29, 1934. 